\title{
THEORETICAL AND METHODICAL APPROACHES TO THE FORMATION AND EVALUATION OF THE QUALITY OF TOURIST SERVICES
}

\author{
Nataliya Vasylykha ${ }^{1}$, Larysa Pavlish ${ }^{2}$ \\ Uzhhorod Institute of Trade and Economics, Ukraine
}

\begin{abstract}
The study, the results of which are described in the article, is devoted to analysing and substantiating approaches to the assessment and quality assurance of tourism services, which form their competitiveness, namely factors and indicators of quality. After all, the integration and globalization of the world society determine the development of tourism as a catalyst for these global processes, and world practice has proved that tourism can be an effective way to solve many socio-economic problems. The subject of the study is the peculiarities of assessing the quality of tourist services. Methodology. The methodological basis of the work is a system of general scientific and special scientific methods, mainly, in the process of research, there are used such methods as system-analytical and dialectical methods - for the theoretical generalization of the investigated material; structural and logical method in systematizing factors and indicators of the quality of tourist services. The purpose of the article is a theoretical justification of approaches to the quality of tourist services and optimization of their quality assessment. In the research, approaches to the interpretation of the concept of quality are presented and analysed, features of services in general and tourism in particular are concentrated, and it is suggested to group and classify factors and indicators of their quality. The interpretation of the notion of quality is ambiguous, both in Ukrainian and in foreign literary sources, and depends on the point of view on this notion. In our opinion, the most thorough definition characterizes the quality of products and services as a complex feature that determines their suitability to the needs of the consumer. Taking into account the specificity of the term "service", peculiarities determining the approaches to their evaluation are studied, such a service can be considered a product dominated by intangible elements and also there are separate material components. The peculiarity of tourist services is that they provide the satisfaction of financial and intangible (spiritual) tourist needs of the person, which includes transportation services, accommodation services, and other travel services, not related to transportation and accommodation. Awareness of factors that determine quality is the starting point for improving it. We carried out an extrapolation of factors of the quality of goods, tourism services as a special type of goods, and made their classification. Quality score is a quantitative or qualitative set of specific requirements for the characteristics (properties) of an object that make it possible to implement and verify them. To determine the quality level, we have suggested a classification of quality indicators of tourism service. Conclusions. Tourist service is considered as a specific activity aimed at creating the conditions for the effective realization and use of tourism product, which is the result of the purposeful activity of the tourist enterprise. Factors of the quality of tourist services should be grouped according to peculiarities of their manifestation (forming, restraining and storing), and managing individual determinants (tourism potential, material base, personnel qualification, marketing research on the relevance and life cycle of services, ongoing maintenance of facilities, timely overhaul of production capacities services, measures of ecological and economic stability, introduction of standards of service and analysis of their observance, material interest personnel, using the principles of quality system) can be directed to act on the overall quality. Indicators of quality of tourist services are pointers of their quality. Establishing the optimal value of a certain quality index (according to the classification suggested in the study) and its comparison with the actual manifestation of this indicator, one can characterize the degree of conformity of the tourist service to its requirements. The latter is aimed at improving the quality of tourist services, and, indirectly, the requirements to them.
\end{abstract}

Key words: quality, service, tourist service, quality factors, quality indicators.

JEL Classification: L15, L83, L84

Corresponding author:

${ }^{1}$ Department of Commodity Research and Commercial Activities, Uzhhorod Institute of Trade and Economics.

E-mail: wasylyha@qmail.com

${ }^{2}$ Department of Commodity Research and Commercial Activities, Uzhhorod Institute of Trade and Economics.

E-mail: pavlish.larisa@gmail.com 


\section{Introduction}

Integration and globalization of society determine the development of tourism as a catalyst for these global processes, which is becoming more and more significant determinant of the socio-economic development of the country. The modern world cannot be imagined without tourism: international organizations are studying, considering and developing ways and opportunities for tourism development, it is planned by national governments, discussed in the media, and in the end, almost every day the average consumer in one way or another touches on tourism.

Tourism has all the features that define it as an independent branch of the economy that arose in the process of social division of labour and covers all kinds of human activities that are aimed at organizing rest and renew people's health.

At the same time, it is logical that the question arises about the quality of tourism services as a specific product since the problem of assessing the quality of services in general and tourism in particular is due to a number of their specific features.

The aim of the study is a theoretical justification of approaches to the quality of tourist services and optimization of their quality assessment.

The subject of the study is peculiarities of assessing the quality of tourism services.

Methodology. The methodological basis of the work is a system of general scientific and special scientific methods; in particular, the following methods were used in the process of research: system-analytical and dialectical methods - for the theoretical generalization of the investigated material; structural-logical method - in systematizing factors and indicators of the quality of tourist services.

The approaches to the interpretation of the concept of quality are presented and analysed in the article, features of services in general and tourism services in particular are concentrated, and it is suggested to group and classify factors and indicators of their quality.

\section{Scientific approaches to the terminology of the quality of tourist services}

The interpretation of the notion of quality is ambiguous, both in Ukrainian and in foreign literary sources, and depends on the point of view on this notion.

Quality is a philosophical concept, from the terminology of the humanities. In Aristotle's logic, quality is one of the 10 categories, on which Aristotle divided all things of reality. As one of such categories, quality is a by-side circumstance with the help of which the thing acquires the qualities of some type; a by-side circumstance that indicates what the thing is (its meaningful qualities and forms) and how it works (its abilities and skills); a by-side circumstance, which is an external valuation form (Shynkaruk, 1986).
The ISO 8402-1986 standard defines quality as a "set of features and characteristics of a product or service that ensures its ability to meet claimed or foreseeable needs."

According to the Law "On Consumer Rights Protection" "the proper quality of goods, jobs or services is a property of a product that meets the requirements established for this category of products in the regulatory acts and regulations, and the terms of the contract with the consumer."

According to UNWTO, quality is a performance at a certain price for any client's tasks and expectations that are not prohibited by law, while respecting the requirements of safety, hygiene, and availability of services, the harmony of the human and natural environment.

Thus, the quality of products and services is a complex feature that determines their suitability to the needs of the consumer.

Taking into account the specificity of the term "service", it is necessary to note features that determine approaches to their evaluation.

Services are products that do not have a real, tangible form, "which exist in the form of useful effective work" (Prokhorov, 1980). Consumption of services mainly occurs at the same time as their production. These are the benefits that cannot be stored and accumulated (Mazur, 2011). Therefore, unlike the market where products are sold in real form, the services market is directly related to the processes of production and consumption. As the classic of marketing thought $\mathrm{P}$. Kotler points out, in this market, there is no transfer of ownership, possession of property (Kotler, 2006). It is not characterized by aposteriority (post-production realization), on the basis of which on the other markets surplus goods are periodically accumulated.

As the most effective sphere of the market from the point of view of consumerinterests, the market of services at the rates of development is increasingly ahead of the market of products manufactured in real form. Such an increase in production and service delivery is the main content of post-industrialization - the transition of modern economies to a new high-quality state (Bulatov, 2005). Prospects for the development of countries and regions in post-industrialization are determined by the development of their market of services, indicators of which become important indicators of socio-economic development.

The market of services is a complex part of a single market space, based on the general market principles of management, namely: freedom of choice, customer orientation, competitive nature of relations. At the same time, it is allocated in a separate direction of research, the general principles of management which have a specific character. The market of services is not similar to other markets mainly due to the following reasons: 1) high level of uncertainty of the service, which prevents the sellers from their promotion on the market; 
2) the impossibility of comparing and evaluating services until their acquisition.

In the economic theory, the service is considered as a special consumer value, expressed in a certain beneficial effect, which satisfies the needs of people and society.

Services are actions, the result of which is consumed in the process of their provision. They represent the activity of the individual in favour of another person, "purposeful activity, the results of which have a manifestation in the beneficial effect" (Lyubitseva, 2006).

In commerce, services are labour-intensive, meaningful activities, the results of which are reflected in the useful effect, the specific consumer value. The feature of the service is the coincidence in time and in space of processes of production, sales, and consumption of its consumable value. Such a definition is enshrined in the Law on Protection of Consumer Rights - the activity of the executor for the provision (transfer) to the consumer of a specified contract of material or intangible good, carried out on individual orders of the consumer to meet his personal needs.

Services are characterized by specific characteristics that distinguish them from other goods: inseparability from the source, intangibility, insecurity, and instability of quality. The abovementioned characteristics mainly determine the specificity of evaluation and standardization of their quality.

To give a comprehensive definition of a service is not an easy task. The difficulty lies in the fact that in practice products are offered that are components of individual services and material goods (for example, passenger air transport services include not only the movement of passengers and luggage in space but also food during the flight). We support the idea that the service can be considered a product dominated by intangible elements and also there are certain material components. In this case, exclusively intangible benefits should be the main motive for the purchase of consumer services.

In the basis of the selection of the market for tourist services or the tourist market, which includes the services of the tourist industry, among the markets for other services lie their specificity and peculiarities of the approach to the interpretation.

Such authors as T. Androsova (2008), A. Chernihovskaya (2007) separate these concepts, based on the fact that in the market for tourist services, in their opinion, there occurs the sale of a specially developed tourist product, while the tourist market is not only a set of services sold but also a corresponding infrastructure that provides its functioning.

Other authors, in particular, O. Lyubitseva, N. Kudla identify these concepts. Thus, O. Lyubitseva points out that "the market of tourist services or the tourist market is an objective basis for the formation of the growth and diversification of social needs and the corresponding deepening of the social division of labour. It is a part of the global services market, its specific component. The tourist market is a sphere of satisfaction of the needs of the population in services related to rest and content of leisure travel" (Lyubitseva, 2006).

Russian author G. Yakovlev (2007) believes that "the tourist industry is a collection of facilities, vehicles, catering, entertainment, objects of cognitive, business, recreational, sports, and other activities, organizations that provide excursion services, as well as services of guides' translators.

In the broader understanding, the tourism industry is considered by O. Lyubitseva. In the framework of the tourism industry, it includes not only enterprises of the tourism industry, but also other elements and structures involved in the organization of tourist consumption. Tourism industry according to O. Lyubitseva (2006) includes three subsystems: organizational and institutional, functional and economic, territorial and economic.

Thus, in the broad sense, the term "tourism industry" includes not only tourist enterprises, hospitality, food, transport facilities, but also state institutions of law, monetary and tax policy, consulting and customs services, tourist resources and population of territories, tourists; and tourism services respectively - the activities to meet the needs of tourists by these enterprises.

Different definitions of tourist services occur in the professional literature (Table 1). Mainly, A. Kornak and M. Montigyer-Loyba (2012), under the term tourist services, mean "any exchange or sale of the results of human labour that is related to the direct or indirect satisfaction of needs before and during the trip and at the place of tourist stay, but is not a consequence of the direct production of objects. They depend on the presence of a tourist customer."

Somewhat differently this concept is defined by V. Gavoretsky (2007), who by the term tourist service understands "any socially useful actions that ensure satisfaction of the material and intangible (spiritual) tourist needs of a man. They are equally related to the maintenance of a tourist (material needs, for example, accommodation, food), and so to his personality (spiritual needs, for example, cultural and entertainment)."

In his turn, R. Lazarek calls tourism services "any actions, which satisfy the needs of tourists connected with the trip and actualize their purpose in the tourist territory, that is, satisfy the needs of tourists before, during, and after the trip." In this definition, the author focuses on the goal of tourism services that is to meet the needs of tourists (Herasymenko, 2013).

In the Law of Ukraine "On Tourism", there is no special definition of the term "tourist service" but there is given a definition of accompanying and tourism services and goods (1995). Accompanying tourism services are understood as services and products designed to meet the needs of consumers, the provision and production 
Table 1

Interpretation of concepts "tourist service" and "tourism product"

\begin{tabular}{|c|c|}
\hline Author, source & Definition of the concept \\
\hline $\begin{array}{l}\text { Law of Ukraine } \\
\text { "On Tourism" (1995) }\end{array}$ & $\begin{array}{l}\text { A tourist product is a pre-designed complex of tourist services that combines not less than } \\
\text { two such services that are being sold or offered for sale at a specified price, which includes } \\
\text { transportation services, accommodation services, and other travel services not related } \\
\text { to transportation and accommodation (services for organizing visits to cultural objects, } \\
\text { recreation and entertainment, sale of souvenirs, etc.). }\end{array}$ \\
\hline $\begin{array}{l}\text { International recommendations } \\
\text { on tourism statistics (2008) }\end{array}$ & $\begin{array}{l}\text { A tourist product is a combination of different aspects (characteristics of places visited, } \\
\text { modes of transport, types of accommodation, activities) around a specific centre of interest } \\
\text { (excursion to a natural reserve, farm stay, visits to historical sites). }\end{array}$ \\
\hline $\begin{array}{l}\text { Glossary of terms on international } \\
\text { tourism (2006) }\end{array}$ & $\begin{array}{l}\text { Tourist product is an orderly set of tourist services, jobs that provide consumption of } \\
\text { tourist services and goods. This is a collection of many elements: natural resources, cultural, } \\
\text { architectural, geographic places of interest, technological capabilities, equipment, and } \\
\text { systems of enterprises of tourism infrastructure. }\end{array}$ \\
\hline V. Kvartalnov (2003, p. 42, 47) & $\begin{array}{l}\text { Tourist services are a segment of the service sector that provides for meeting the needs of } \\
\text { people and implementing their activities in their free time: rest, entertainment, travel. } \\
\text { A tourist product is a collection of real (consumer items) and non-real (services) consumer } \\
\text { values necessary for the full satisfaction of the needs of tourists that appear during their } \\
\text { travel. }\end{array}$ \\
\hline I.M. Shkola (2005, p. 9) & $\begin{array}{l}\text { Tourist services are services of subjects of tourist activity in relation to accommodation, } \\
\text { food, transport, informational and advertising services, as well as services of cultural, sport, } \\
\text { everyday life, entertainment, etc., aimed at satisfying the needs of tourists. } \\
\text { Tourist product is a complex of tourist services necessary to meet the needs of the tourist } \\
\text { during his travel. }\end{array}$ \\
\hline A.P. Durovych (2004, p. 61-62) & $\begin{array}{l}\text { Tourist product is the result of social labour in the form of tourist services, which have a } \\
\text { consumer value. In the broad sense, tourist product is any kind of tourist services. } \\
\text { Tourist services are the purposeful production activity, which satisfies the needs of tourists } \\
\text { and does not accept, as a rule, material form. Tourist services can be characterized as invisible } \\
\text { goods of a special kind. }\end{array}$ \\
\hline
\end{tabular}

of which will be reduced significantly without their implementation for tourists, and typical tourist services and goods are designed to meet the needs of tourists, the provision and production of which will be significantly reduced without their implementation for tourists.

The generalization of approaches to the definition of the essence of tourist services allows us to identify their main functions, namely:

- economic, which stimulates the development of branches of the economy, increases the standard of living of the population;

- technological, which serves as a means of delivery of goods to meet the basic needs of tourists and tourist destinations;

- providing, which creates the appropriate conditions for the consumer (rest, treatment, business, shopping, etc.) outside the place of his permanent residence.

According to the recommendations of the World Tourism Organization UNWTO, the quality of tourism is interpreted as an element of quality of life during the temporary stay of tourists outside the place of permanent residence.

\section{Factors of the quality of tourist services}

Awareness of the factors that determine the quality is the starting point for improving it (Strokovych, 2010).
We will extrapolate the quality of goods and travel services as a special type of goods (Fig. 1).

As can be seen from the figure, the factors of the quality of tourist services, similar to the goods, are proposed to be divided into three groups. The factors that directly shape the quality of expediency include: tourism potential, material resources of the enterprise and the conditions of service, qualifications of the staff.

To the factors that maintain quality, we refer: research on the life cycle of services, ongoing maintenance and overhaul of the material base, the application of measures to preserve the tourism potential, etc.

It is expedient to include the development and implementation of service standards, the analysis of the accuracy of their compliance, the material and moral interest of the personnel, and the use of principles of the quality system.

Analysing the proposed classification of factors of the quality of tourist services, one can mention those that can be regulated and unregulated factors that do not depend on the activity of the enterprise providing the services. And if the enterprise can only indirectly influence the initial tourist potential of the region, then other factors can be optimized by means of certain strategically directed measures. Such measures should be based on identified indicators, indicators of the quality of tourist services. 


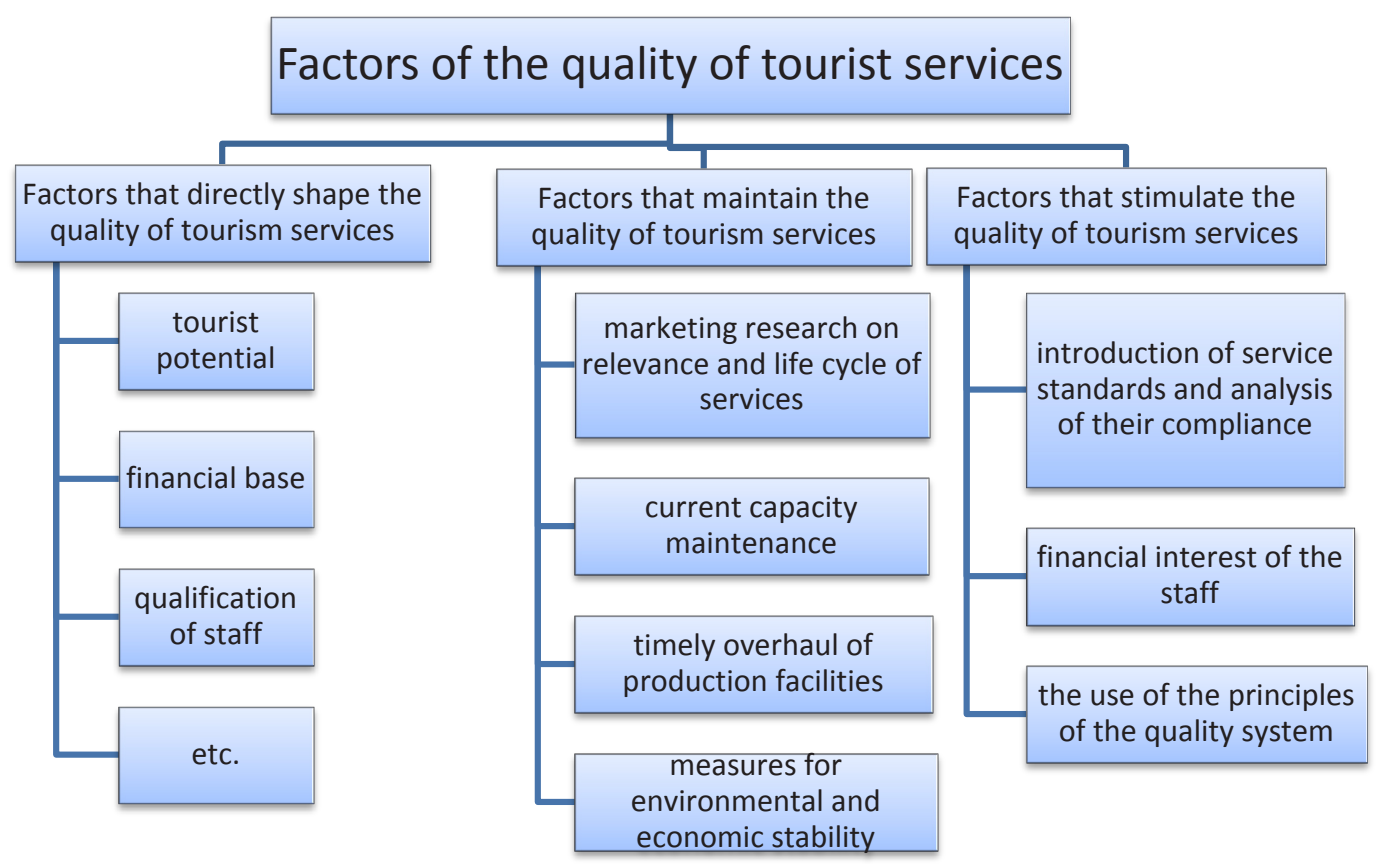

Fig. 1. Factors of the quality of tourist services

\section{Basic indicators of the quality of tourist services}

Quality score is a quantitative or qualitative set of specific requirements for the characteristics (properties) of an object that make it possible to implement and verify them.

To determine the quality level, we have suggested the main indicators of the quality of tourist services (Fig. 2).

Consequently, understanding the concept of the quality of tourism services, as a combination of individual indicators, will allow rationally evaluating it and maximally optimizing the standards of service in the tourism industry, taking into account factors of its quality.

\section{Quality tools for tourist services}

It should be noted that for measuring travel services, there are: standards, technical and commodity norms, the culture of service, consumer rights protection, etc.

At the same time, the standardization itself (state, public, mixed) in the sphere of tourism business should be considered also in the sphere of protection of consumer interests. In conditions of market relations, any activity, including tourism, requires unification and standardization. First of all, it concerns the offered services. What concerns tourism communication, experience, they cannot be a priori standar dized, since one of the main motives of a tourist trip is the desire for acquaintance and direct contact with the unique, original culture of certain people who are spatially localized.
Therefore, speaking about standardization in the tourism business, one should speak not about the standardization of social and cultural diversity, but about the standardization of levels of comfort - those parties and the properties of services that have a consumer value and, therefore, should have a guaranteed equivalent of quality, comfort, security, etc. All other aspects of the tourist trip are and must be unique, ethnically or regionally conditioned. Such standardization is undesirable (Alexandrova).

However, it should be noted that the quality assessment also depends on the client's expectations, which in turn is determined by the personal needs of the individual, the client's prior experience and the exchange of experience between clients. Only the client can assess the relevance of the service to their perceptions, the purpose of the service, its duration, availability, speed, and cultural level of service.

In order to ensure the high quality of tourist services, enterprises develop and use internal standards of service for the employed, that is aimed at the stability of the provision of tourist services and are unconditional for the performance of a particular enterprise. Such standards are organizational and guidance, methodological documents that reflect requirements to goals, organizations, technologies, and the provision of certain types of work.

They have a multi-purpose meaning, as they serve the function of the instruction, the textbook for learning and the basis for control. Our quality indicators, classified by blocks, can be used as a basis for tourism service standards and, accordingly, used for the purposes mentioned above. 


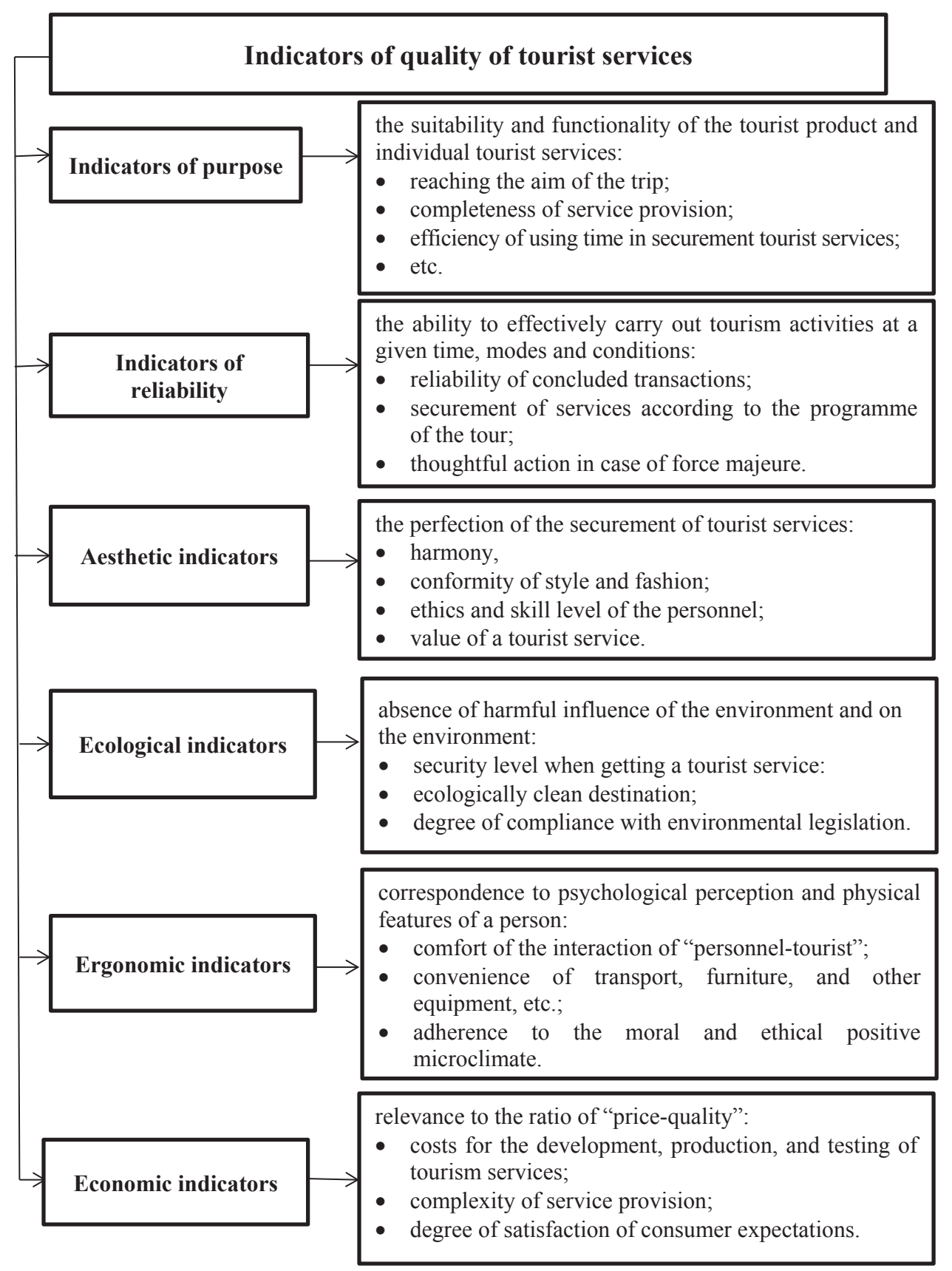

Fig. 2 Indicators of quality of tourist services

\section{Conclusions}

Tourist service is considered as a specific activity aimed at creating the conditions for the effective realization and use of tourism product, which is the result of the purposeful activity of the tourist enterprise.

Factors of the quality of tourist services should be grouped according to the peculiarities of their manifestation (forming, restraining and storing), and managing individual determinants (tourism potential, material base, personnel qualification, marketing research on the relevance and life cycle of services, ongoing maintenance of facilities, timely overhaul of production capacities services, measures of ecological and economic stability, introduction of standards of service and analysis of their observance, material interest personnel, using the principles of quality system) can be directed to act on the overall quality.

Indicators of quality of tourist services are pointers of their quality. Establishing the optimal value of a certain quality index (according to the classification suggested in the study) and its comparison with the actual manifestation of this indicator can characterize the degree of conformity of the tourist service to its requirements. The latter is aimed at improving the quality of tourist services, and, indirectly, the requirements to them. 


\section{References:}

Aleksandrov, V. V. (2010). Turyzm v systemi priorytetiv rehionalnoho rozvytku: monohrafiya [Tourism in the system of regional development: monograph]. Kharkiv: KhNU imeni V.N. Karazina (in Ukrainian).

Androsova, T. V., Shtal, T. V., Opalenyk, A. V. (2008). Zakonomirnosti funktsionuvannya rynku turystychnykh posluh [The regularities of the functioning of the tourist services market]. Economic strategy and prospects for the development of trade and services. vol.1 (7): Economics, pp. 324-331.

Birzhakov, M. B., Nikiforov, V. I. (2006). Bolshoy Glossariy terminov mezhdunarodnogo turizma [The Great Glossary of Terms for the International Tourism], Sankt-Peterburg: Gerda (in Russian).

Bulatov, A. S. (ed.) (2005). Mirovaya ekonomika [World economy]. Moscow: Ekonomist (in Russian).

Chernykhivska, A. V. (2007). Napryamy doslidzhennya sfery turystychnykh posluh u formati rehionalnoho rozvytku [Areas of study of tourism services in the format of regional development]. Scientific journal. vol. 18, pp. 41-45.

Durovich, A. P. (2004). Marketing v turizme (Marketing in Tourism), Minsk: Novoe znamya (in Russian).

Gaworecki, W. (2007). Tyrystyka [Tourism]. Warszawa : Polskie Wydawnicto Economiczhe. (in Polish).

Herasymenko, V.H. (ed.) (2013). Rynky turystychnykh posluh : stan i tendentsiyi rozvytku : monohrafiya [Markets of tourist services: the state and trends of development: monograph]. Odesa : Astroprynt (in Ukrainian).

ISO 8402:1986. Quality - Vocabulary.

Kotler, P. (ed.) (2006). Osnovy marketinga [The basics of marketing]. Moscow: Vilyams. (in Russian).

Kudla, N. Ye. (2012). Turystychna posluha - skladova produktu [Tourist service is a component of the product]. Menedzhment turystychnoho pidpryyemstva [Management of a tourist enterprise]. Retrieved from: http://westudents.com.ua/knigi/602-menedjment-turistichnogo-pdprimstva-kudla-n.html (accessed January 2018).

Kvartalnov, V. A. (2003). Teoriya i praktika turizma [Theory and practice of tourism]. Moscow: Finansy i statistika (in Russian).

Lyubitseva, O. O. (2006). Rynok turystychnykh posluh (heoprostorovi aspekty): monohrafiya [Market of tourist services (geospatial aspects): a monograph]. Kyyiv: Alterpres. (in Ukrainian).

Mazur, Yu. P. (2011). Diyalnist pidpryyemstv na rynku turystychnykh posluh [Activity of enterprises in the market of tourist services]. Collection of scientific works of Uman National University of Horticulture, vol.75, part 2: Economics, pp. 223-228.

Mezhdunarodnye rekomendatsii po statistike turizma (2008). [International recommendations on tourism statistics]. Retrieved from: http://unstats.un.org/unsd/publication/SeriesM/Seriesm_83rev1r.pdf (accessed December, 2017).

Pro turyzm: Zakon Ukrayiny [The Law of Ukraine "On tourism”] № 324/95-BP (1995) Retrieved from: http://zakon4.rada.gov.ua/laws/show/324/95-вp (accessed December, 2017).

Prokhorov, A. M. (ed.) (1980). Bolshaya sovetskaya entsiklopediya [The Great Soviet Encyclopedia]. Moscow: Sovetskaya entsiklopediya. (in Russian).

Shkola, I. M. (ed.) (2005). Menedzhment turystychnoyi industriyi [Management of tourism and industry], Chernivtsi : Knyhy-XXI (in Ukrainian).

Shynkaruk, V. I. (1986). Filosofskyy slovnyk [Philosophical dictionary]. Kyyiv (in Ukrainian).

Strokovych, H. V. (2010). Yakist funktsionuvannya pidpryyemstva: vnutrishni ta zovnishni aspekty : monohrafiya [Quality of operation of the enterprise: internal and external aspects]. Kharkiv: NUA (in Ukrainian).

Yakovlev, G. A. (2007). Ekonomika i statistika turizma [Economics and statistics of tourism]. Moscow: RDL (in Russian). 